\title{
ВПЛИВ ЗБАЛАНСОВАНИХ РАЦІОНІВ ГОДІВЛІ НА МОЛОЧНУ ПРОДУКТИВНІСТЬКОРІВ, ОБМІН РЕЧОВИН ТА ЕФЕКТИВНІСТЬ КОНВЕРСІЇ КОРМУ У МОЛОКО
}

Борщенко Валерій Володимирович доктор сільськогосподарських наук, доцент Поліський національний університет ORCID: 0000-0002-0710-5628

E-mail: kafgodivlya@ukr.net

Лавринюк Оксана Олександрівна кандидат сільськогосподарських наук, доцент Поліський національний університет ORCID: 0000-0003-3145-3689

E-mail: oksana lavren@ukr.net

Солоненко Наталія Ігорівна студентка

Поліський національний університет ORCID: 0000-0002-5987-9393 E-mail: nataliiasolonenko01@gmail.com

Солоненко Євгеній Леонідович студент

Поліський національний університет ORCID: 0000-0002-7829-6628

E-mail: zheka1357@gmail.com

Крисан Сергій Васильович студент

Поліський національний університет ORCID: 0000-0001-7300-449X E-mail: mailto:tehnologznaeu@gmail.com

Виробничі дослідження щодо оцінки впливу збалансованих раціонів годівлі на молочну продуктивність корів, обмін речовин та ефрективність перетворення кормів у молоко проводилось на поголів"ї української чорно-рябої породи ПСП «Новоселиця» Попільнянського району Житомирської області, у кількості 36 голів. Корови перебували у другому періоді лактації, середньодобове виробництво молока становило 13,9 ке з 4,1\% жиру. У ході досліджень були оптимізовані раціон із найменшими витратами, використовуючи програмне забезпечення для балансування раціонів. Раціон був збалансований за обмінною енергією, сирим протеїном, кальцієм та фосфором, відповідно із нормами годівлі для великої рогатої худоби. Збалансованими раціонами годували всіх експериментальних тварин протягом 30 днів, за винятком 15-денного періоду адаптації. Годівля корів збалансованими раціонами та поліпшення забезпечення кальцієм і фоссрором позитивно вплинула на збільшення надою молока4\% жирності на 0,7 ке/корову ( $<<0,05)$. Одночасно зменшилася вартість годівлі на 17,0\%. Оптимізація раціонів дозволяє поліпшити обмінні процеси в організмі корів, аналогічні дослідження свідчать, що рівень вмісту в кровіімуноглобулінів та сечової кислоти значно збільшується, тоді як рівень азоту сечовини крові (BUN) знижується $(P<0,01)$ з 18,2 до 15,0 мг/дл. Також поліпшується конверсія кормів у молоко з 0,8 до 1,0. Дане дослідження свідчить про те, що збалансована годівля корів, після корекції раціонів відповідно до норм годівлі, покращує виробництво молока, поліпшує обмінні процеси в організмі та ефективність перетворення кормів у коріву виробничих умовах. Отже, годівля збалансованим раціоном молочних корів покращує використання поживних речовин, виробництво молока, мікробне забезпечення азотом та ефективність перетворення кормів в продукцію.

Ключові слова: раціони, молочна продуктивність, корови, обмін речовин, ефективність, конверсія корму.

DOI: https://doi.org/10.32845/bsnau.Ivst.2021.3.16

Молочна худоба використовує значну частку спожитих кормів на підтримання життєвих функцій організму, що призводить до високого рівня викидів продуктів обміну у навколишнє середовища та зменшує продуктивну дію раціонів. Крім того, низькоякісні корми, такі як солома та інші неякісні корми, мають низький рівень засвоюваності, а отже, сприяють збільшенню викидів на одиницю спожитого корму. За таких обставин стратегії годівлі, а саме збалансовані Вісник Сумського національного аграрного університету раціони дозволяють покращити продуктивність тварин та поліпшити ефективність використання кормів (Bayat and Shingfield, 2012; Garg et al, 2013; Віттенберг, 2008). Точна годівля тварин, відповідно до їх потреб у поживних речовинах, мінімізує втрату поживних речовин, викиди парникових газів на одиницю продукту та максимізують виробництво молока. Точна годівля має опосередкований вплив на здоров'я рубця та максимізацію мікробного синтезу білка, що 
важливо для поліпшення ефективності використання кормів та зменшення викидів продуктів обміну у навколишнє середовище. Дане дослідження було проведено у виробничих умовах Житомирської області для оцінки впливу збалансованих раціонів на виробництво молока, метаболіти та ефективність перетворення кормів в організмі корів.

Матеріали та методи досліджень. Для дослідження було обрано поголів'я української чорно-рябої породи в ПСП «Новоселиця» Попільнянського району Житомирської області у кількості 36 голів. Корови перебували у другому періоді лактації, середньодобове виробництво молока становило
13,9 кг з 4,1\% жиру.

У ході досліджень були оптимізовані раціон із найменшими витратами (табл. 1), використовуючи програмне забезпечення для балансування раціонів. Раціон був збалансований за обмінною енергією, сирим протеїном, кальцієм та фосффором, відповідно із нормами годівлі для великої рогатої худоби (Калашніков А. П. та ін. 2003; NRC, 2001). Збалансованими раціонами годували всіх експериментальних тварин протягом 30 днів, за винятком 15-денного періоду адаптації.

Таблиця 1

Інгредієнти та хімічний склад раціону до та після його балансування

\begin{tabular}{|l|c|c|c|c|c|}
\hline \multicolumn{4}{|c|}{ Компоненти або інгредієнти раціону (\%) } & \multicolumn{3}{c|}{ Хімічний склад раціону (в перерахунку на суху речовину) } \\
\hline Компонент раціону & $\begin{array}{c}\text { Раціон до } \\
\text { балансування }\end{array}$ & $\begin{array}{c}\text { Раціон після } \\
\text { балансування }\end{array}$ & Поживні речовини корму & $\begin{array}{c}\text { Раціон до } \\
\text { балансування }\end{array}$ & Раціон після балансування \\
\hline Комбікорм & 18,86 & 24,43 & ОЕ (МДж/кг СР) & 9,50 & 9,88 \\
\hline Макуха соняшникова & 3,58 & 1,87 & Органічна речовина (\%) & 89,62 & 88,48 \\
\hline Висівки пшеничні & 20,79 & 18,74 & Сирий протеїн (\%) & 13,11 & 12,94 \\
\hline Кукурудзяний силос & 30,12 & 26.80 & Сира клітковина (\%) & 31,83 & 31,50 \\
\hline Сінаж люцерни & 13,95 & 14,93 & Цукор+крохмаль (\%) & 16,96 & 16,37 \\
\hline Сіно & 6,47 & 6,80 & Сира зола (\%) & 10.38 & 11.52 \\
\hline Ячмінна солома & 6,20 & 5,31 & Са (\%) & 0,31 & 0,60 \\
\hline Мінеральна добавка & 0 & 1,12 & Р (\%) & 0,25 & 0,39 \\
\hline
\end{tabular}

Споживання корму окремою коровою визначали груповим методом за результатами обліку кормів та кормових залишків згідно з екраном технолога. В ході досліджень використовували дані підприємства щодо аналізів зразків повно-змішаного раціону та окремих видів кормів. Протягом експерименту проводився щоденний облік надоїв на доїльній установці та проводився аналіз складу молока з допомогою аналізатора молока «Екомілк» та діагностичних тестсмужок на сечовину.

В ході досліджень також проаналізовані літературні дані: Sherasia P.L. et al. (2016) та інших авторів, щодо оцінки мікробного синтезу у рубці на основі аналізу параметрів сечі і крові корів.

Дані статистично аналізували за допомогою програмного пакету EXEL. Загальні відмінності між варіантами вважалися значущими, при $\mathrm{P}<0,05$. Отримані дані були представлені як середнє значення \pm SE.

Результати досліджень. Сучасна практика годівлі свідчить, що використання комбікормів молочними коровами $€$ поширеною практикою серед виробників молока. Окремі молочні господарства додатково використовують соєвий шрот, соняшникову макуху або інші протеїнові корми як джерело білка для годівлі своїх тварин. Силос кукурудзи, сінаж люцерни, сіно та солома та місцеві трави використовуються як основний корм. Додавання мінеральної суміші для конкретних районів (Са 21,0\% і Р 8,5\%) загалом не широко практикуєтьсяв господарствах, але її необхідно включати у склад збалансованих раціонів (табл. 1). Хімічний склад повно-змішаного раціону та окремих кормів, пропонованих протягом досліджуваного періоду, представлений у таблиці 1 та 2. Споживання сирого протеїну та обмінної енергіїдо балансування раціону було вищим на 12,9 та 8,7\% порівняно з потребами, тоді як споживання Са та $\mathrm{P}$ було нижчим на 59,3 та 69,1\% відповідно, порівняно із потребами (табл. 1).

Хімічний склад окремих видів кормів (в перерахунку на суху речовину)

\begin{tabular}{|l|c|c|c|c|c|c|c|}
\hline \multicolumn{1}{|c|}{ Вид корму } & Органічна речовина, \% & ОЕ, МДж Сирий протеїн, \% & Сира клітковина, \% & Сира зола, \% & Са, \% & P, \% \\
\hline Комбікорм & 87,6 & 11,2 & 19,8 & 2,7 & 12,4 & 1,3 & 1,4 \\
\hline Макуха соняшникова & 92,7 & 10,0 & 34,9 & 20,8 & 7,3 & 0,3 & 0,7 \\
\hline Висівки пшеничні грубого помолу & 94,8 & 9,4 & 15,5 & 13,2 & 5,2 & 0,1 & 1,1 \\
\hline Висівки пшеничні тонкого помелу & 95,5 & 9,6 & 16,2 & 13,3 & 4,5 & 0,1 & 0,9 \\
\hline Сінаж люцерни & 88,2 & 10,4 & 17,3 & 22,1 & 11,8 & 1,3 & 0,4 \\
\hline Кукурудзяний силос & 88,8 & 10,8 & 9,6 & 20,2 & 11,2 & 0,5 & 0,2 \\
\hline Ячмінна солома & 91,5 & 6,8 & 4,8 & 42,6 & 8,5 & 0,3 & 0,1 \\
\hline Сіно & 92,2 & 9,4 & 13,0 & 26,5 & 7,8 & 0,8 & 0,2 \\
\hline
\end{tabular}

Годівля корів збалансованими раціонамисприяла збільшенню живої маси тваринз 593,5 до 598,7 кг (табл. 3).

В той же час зменшилося споживання сухої речовини раціону на $14,5 \%$ ( $P<0,01)$, що відобразилося на зменшенні споживання сирого протеїну та обмінної енергії з 2,17 до 1,84 кг / день та з 157,7 до 140,3 МДж/ день відповідно. Споживання Са та P (г/д) у корів покращилось 3 45,2 до 64,6 та 32,1 до 44,0 відповідно. Більш низьке споживання сухої речовини, сирого протеїну та обмінної енергії після корекції раціону було головним чином обумовлено більш обмеженим споживанням раціону, який до поліпшення раціону згодовувався тваринам у надлишковій кількості.Гарг та ін. (2013) також повідомили, що близько $71 \%$ корів, що годують незбалансованими раціонами споживають більше сирого протеїну та обмінної енергії порівняно з їх потребою. 
Споживання поживних речовин та показники молочної продуктивності та ефективність конверсії корму в молоко корів

\begin{tabular}{|c|c|c|}
\hline Показники & Раціон до балансування & Раціон після балансування \\
\hline Жива маса корів (кг) & $593,5 \pm 6,98$ & $598,7 \pm 6,91$ \\
\hline Споживання сухої речовини раціону (кг/день) & $16,6 \pm 0,53$ & $14,2^{a} \pm 0,49$ \\
\hline Споживання сирого протеїну (кг/день) & $2,17 \pm 0,10$ & $1,84 \pm 0,07$ \\
\hline ОЕ (Мдж/день) & $157,7 \pm 4,94$ & $140,3 \pm 4,44$ \\
\hline Са (г/день) & $51,2 \pm 3,33$ & $84,6 \pm 2,50$ \\
\hline $\mathrm{P}$ (г/день) & $41,5 \pm 1,94$ & $55,0 \pm 1,99$ \\
\hline Надій молока (кг/день) & $13,9 \pm 0,18$ & $14,4^{\mathrm{A}} \pm 0,16$ \\
\hline Надій молока 4\% жирності (кг/день) & $14,0 \pm 0,18$ & $14,7^{\mathrm{A}} \pm 0,16$ \\
\hline Молочний жир (\%) & $4,1 \pm 0,09$ & $4,1 \pm 0,09$ \\
\hline Білок молока (\%) & $3,0 \pm 0,05$ & $3,1 \pm 0,05$ \\
\hline Лактоза (\%) & $4,6 \pm 0,04$ & $4,5 \pm 0,04$ \\
\hline Азот сечовини молока (MUN) (мг/100 мл) & $13,1 \pm 0,64$ & $9,2^{\mathrm{a}} \pm 0,52$ \\
\hline Собівартість 1 кг молока (грн.) & $11,0 \pm 0,79$ & $9,1 \pm 0,43$ \\
\hline Коефріцієнт конверсії корму в молоко (надій, кг/споживання сухої речовини раціону, кг) & $0,8 \pm 0,03$ & $1,0^{a} \pm 0,03$ \\
\hline
\end{tabular}

Цифри, що містять різні верхні індекси, суттєво відрізняються, велика літера $(P<0,05)$, мала літера $(P<0,001)$

Більш високе споживання Са і Р після згодовування збалансованих раціонів було головним чином за рахунок включення в раціон корів мінеральної суміші, яка відповідає потребі.

Надій молока, його склад та економічність виробництва молока. Збалансована годівля покращила $(\mathrm{P}<0,05)$ надої молока фактичної жирності (кг/добу) та надої молока 4\% жирності (кг/добу) на 3,6 та 5,0\% відповідно (табл. 3). Подібні висновки про поліпшення надою молока фактичної жирності та надої молока 4\% жирності внаслідок надходження дефіцитних поживних речовин у лактуючих жуйних тварин повідомляли Haldar та Rai (2003). Вміст молочного білка також поліпшився 3 3,0 до 3,1\% після згодовування збалансованого раціону коровам. Повідомляється, що добавки мінеральних речовин до раціону корів покращують надої молока та склад молока (Khochare et al., 2010). Збалансована годівля корів також була корисною для зменшення (P $<0,001)$ витрат на виробництво молока (корм/кг молока) на $17,0 \%$.

Азот сечовини молока (MUN) зменшився (P <0,001) з 13,1 до 9,2 мг / 100 мл після годування корів збалансованим раціоном (Таблиця 3). MUN - це частина молочного білка, що отримується з BUN, і є корисним інструментом для оцінки білкового та енергетичного стану молочних корів. Надлишок MUN (> 12,0 мг / 100 мл) свідчить про дисбаланс білка, дефіцит вуглеводів або слабкий мікробний синтез білка в рубці (Hutjens and Chase, 2012). Високий рівень MUN перед балансуванням раціону, можливо, вказує на втрату корів кормового білка. Годівля збалансованим раціоном зменшило споживання сирого протеїну і тим самим знизило рівень MUN у корів.

Ефективність перетворення корму. Збалансований раціон годівлі покращив ( $\mathrm{P}<0,001)$ ефективність перетворення корму (кг виробленого молока на кг спожитої сухої речовини раціону) з 0,8 до 1,0 у корів (табл. 3). Ці висновки узгоджуються $з$ попередніми звітами (Shahjalal etal., 2000; Castillo et al., 2001; Garg et al., 2013).

Оцінка мікробниго синтезу білка на основі аналізу специфічних параметрів сечі та крові.

Показним у цьому питанні є дослідження Sherasia
P.L. et al. (2016), у якому концентрація в сечі PD (алантоїну та сечової кислоти) покращилася після згодовування коровам збалансованих раціонів (13,5 проти 17,8 ммоль / л; Р $<0,001 ;$ табл.4)

В подібних до наших дослідженнях Sherasia P.L. et al. (2016) для оцінки метаболізму азоту відбиралися зразки сечі (100 мл) у окремих тварин до і після згодовування збалансованих раціонів з наступним їх зберіганням із достатньою кількістю 1,87 моль/л $\mathrm{H}_{2} \mathrm{SO}_{4}$ для підтримання $\mathrm{pH}<3$. В подальшому зразки сечі розводили для оцінки похідних пурину (PD). Зразки сечі аналізували на алантоїн, сечову кислоту та креатинін (Hawk et al., 1976). Екскреція PD вимірювалася, виходячи з того, що виведення креатиніну постійне протягом доби; креатинін використовували як внутрішній маркер для оцінки PD (Chen et al., 1992). Щоденна екскреція креатиніну вважалася 0,98 ммоль/кг W075 (Makkar and Chen, 2004). Поглинання пуринів та надходження мікробного азоту розраховувались на основі щоденного виділеного PD 3 сечею (IAEA, 1997).

Згідно досліджень Sherasia P.L. et al. (2016) надходження мікробного N в дванадцятипалу кишку $є$ важливим показником ефективності функції рубця. Екскреція алантоїну з сечею була успішно використана для оцінки мікробного $\mathrm{N}$, синтезованого в рубці і згодом перетравленого в кишківнику жуйних тварин (Ramgaokar etal., 2008). Годівля корів відповідно до потреб поживних речовин призвела до поліпшення індексу PDC, виведення та поглинання пуринів, таким чином, покращення надходження кишкового мікробного азоту на 36,9\% (таблиця 4). У цьому дослідженні дисбаланс білка, енергії та мінеральних речовин перед балансуванням раціону може бути причиною поганої доступності АТФ для виробництва мікробних клітин, тим самим зменшуючи мікробний синтез N. Після годівлі корів збалансованим раціоном, правильний баланс поживних речовин міг призвести до вищого синтезу $\mathrm{N}$ мікробів, що покращило продуктивність тварин. Забезпечення достатньою кількістю поживних речовин збільшує виведення з сечею PD, синтез мікробного білка рубця та посилює його надходження для виробництва молока (Makkar and Chen, 2004). 
Параметри сечі тварин за даними Sherasia P.L. et al. (2016)

\begin{tabular}{|l|c|c|}
\hline \multicolumn{1}{|c|}{ Досліджувані параметри } & Раціон до балансування & Раціон після балансування \\
\hline Алантоїн (ммоль/літр) & $11,1 \pm 0,28$ & $14,2^{a} \pm 0,48$ \\
\hline Сечова кислота (ммоль/літр) & $2,4 \pm 0,19$ & $3,6^{a} \pm 0,34$ \\
\hline Креатинін (ммоль/л) & $7,0 \pm 0,26$ & $7,0 \pm 0,29$ \\
\hline Похідні пурину: алантоїн+сечова кислота (PD) (ммоль/л) & $13,5 \pm 0,36$ & $17,8^{a} \pm 0,63$ \\
\hline Індекс РDС (відношення між похідними пурину і креатиніном) & $170,3 \pm 6,99$ & $228,4^{a} \pm 10,57$ \\
\hline Загальна кількість екскретованих похідних пурину (PD) (ммоль/добу) & $166,9 \pm 6,85$ & $223,8^{a} \pm 10,36$ \\
\hline
\end{tabular}

Цифри, що містять різні верхні індекси, суттєво відрізняються: мала літера $(P<0,001)$

Параметри крові. Зразки крові у дослідженнях Sherasia P.L. et al. (2016) відбирали перед годівлею з яремних вен окремої корови у герметичні пробірки з ЕДТА. Плазму готували після центрифугування крові при 1000 обертах протягом 5 хв і заморожували для подальшого біохімічного аналізу крові. Зразки аналізували на наявність імуноглобулінів, таких як $\lg$, $\lg M$ та $\lg A$, та азоту сечовини крові (BUN), згідно з методом Rahmatullah and Boyde (1980).

Як свідчать дані таблиці 5, збалансована годівлякорів покращила кількість імуноглобулінів $\lg$ та $\lg$ А з 17,3 до $23,4(\mathrm{P}<0,05)$ та 0,2 до 0,3 мг/мл $(\mathrm{P}<0,001)$ відповідно та $\operatorname{lgM} 3$ 1,3 до 2,4 мг/мл ( $P<0,001)$. Спірс (2000) повідомляє, що дисбаланс поживних речовин може змінити активність ферментів, тим самим погіршуючи імунну функцію. Функціональність численних структурних білків, ферментів та клітинних білків залежить від поживних речовин, включаючи мінерали, що потрапляють у організм у відповідних кількостях (Nocek et al., 2006). У цьому дослідженні корекція раціонів могла збільшити доступність дефіцитних поживних речовин для тварин, що більше стимулювало метаболізм імунних клітин і, таким чином, покращувало гуморальний імунний статус тварин за рахунок більш високої продукції lgG. Більше того, фоссрор асоціюється зі стимуляцією імунної функції, забезпечуючи АТФ імунними клітинами. Оскільки десріцит Р був поширеним до балансування раціону, збалансування раціону в цьому дослідженні могло стимулювати імунну функцію молочних тварин шляхом надання АТФ імунним клітинам. Ці дані подібні до результатів досліджень Kiersztejn et al. (1992). BUN зменшився ( $P<0,05)$ після згодовування збалансованого раціону коровам (з 18,2 до 15,0 мг/дл), що аналогічно значенню (12 мг/дл) у великої рогатої худоби, про яке повідомляють Kohn et al. (2005). Концентрація BUN є хорошим показником білкового статусу молочних тварин (Kohn et al., 2005). Концентрація аміаку в рубці збільшується при надлишку азоту відносно енергії в рубці. Надлишок аміаку перетворюється у сечовину в печінці. Утворена таким чином сечовина циркулює в крові і виводиться через сечу або знову потрапляє в рубця через слину або дифундує з крові в молоко. У цьому дослідженні також надлишок сирого протеїну перед балансуванням і корекцією раціону міг збільшити рівні BUN та MUN у корів (табл. 5). У корів, які споживали збалансований раціон, споживання сирого протеїну було нижчим, а отже, у цьому дослідженні спостерігався нижчий рівень BUN та MUN. BUN має високу кореляцію з аміаком рубця (Hennessy and Nolan, 1988), а MUN - з BUN (Baker et al, 1995; Butler et al, 1996).

Таблиця 5

Параметри крові піддослідних тваринза даними Sherasia P.L. et al. (2016)

\begin{tabular}{|l|c|c|}
\hline \multicolumn{1}{|c|}{ Досліджувані параметри } & Раціон до балансування & Раціон після балансування \\
\hline Креатинін (мг/дл) & $1,2 \pm 0,02$ & $1,1 \pm 0,03$ \\
\hline Сечова кислота (мг/дл) & $2,0 \pm 0,16$ & $2,8 \pm 0,18$ \\
\hline Імуноглобуліни (IgG, мг/мл) & $17,3 \pm 1,99$ & $23,4^{\mathrm{A}} \pm 2,33$ \\
\hline Iмуноглобуліни (IgA, мг/мл) & $0,2 \pm 0,02$ & $0,3^{\mathrm{a}} \pm 0,03$ \\
\hline Імуноглобуліни (IgM, мг/Мл) & $1,3 \pm 0,20$ & $2,4^{\mathrm{a}} \pm 0,32$ \\
\hline Азот сечовини крові (BUN, мг/дл) & $18,2 \pm 0,93$ & $15,0^{\mathrm{A}} \pm 1,01$ \\
\hline
\end{tabular}

Цифрри, що містять різні верхні індекси, суттєво відрізняються, велика літера $(P<0,05)$, мала літера $(P<0,01)$

Висновки. Годівля збалансованим раціоном молоч- $\mid$ ництво молока, мікробне забезпечення азотом та ефективних корів покращує використання поживних речовин, вироб- $\quad$ ність перетворення кормів в продукцію.

\section{Список використаної літератури:}

1. Нормы и рационы кормления сельскохозяйственных животных : справ. пособие. 3-е издание перераб. и доп. под ред. А. П. Калашникова, и др. Москва, 2003. 456 с.

2. Baker L. D., Ferguson J. D., Chalupa W., Responses in urea and true protein of milk to different protein feeding schemes for dairy cattle. J. Dairy Sci. 1995. issue 78. pp. 2424-2434.

3. Bayat A., Shingfield K. J, Overview of nutritional strategies to lower enteric methane emissions in ruminants. In 'Proceeding of Maataloustieteen Paivat, Helsinki, Finland. 2012. pp. 1-7.

4. Castillo A. R., Kebreab E., Beever DE., Barbi J. H., Sutton J. D., Kirby H. C., France J. The effect of protein suppleme tation on nitrogen utilisation in lactating dairy cows fed grass silage diets. J. Anim. Sci. 2001. issue 79. pp. 247-253.

5. Garg M. R., Sherasia P. L., Bhanderi B. M., Phondba B. T., Shelke S. K. and Makkar H.P.S. Effects of feeding nutri?ionally balanced rations on animal productivity, feed conversion efficiency, feed nitrogen use efficiency, rumen microbial protein supply, parasitic load, immunity and enteric methane emissions of milking animals under field conditions. Anim. Feed Sci. Technol. 2013. issue 179. pp. 24-35.

6. Haldar S., Rai S. N. Effects of energy and mineral supplementation on nutrient digestibility and efficiency of milk production in lactating goats. Indian J. Anim. Nutr. 2003. issue 20, pp. 244-251. 
7. Hawk P. B., Oser B. L., Summerson W. H. 1976. 'Physiological Chemistry.' 14th edn. (McGraw Hill Publishing Company Ltd.: London, UK).

8. Hennessy D. W., Nolan J. V. Nitrogen kinetics in cattle fed a mature subtropical grass hay with and without protein meal supplementation. Aust. J. Agric. Res. 1988. issue 39. pp. 1135-1150.

9. Hutjens M., Chase L. E., 2012. Interpreting milk urea nitrogen (MUN) values. Extension - America's research-based learning network. http://www.extension.org/

10. IAEA (1997). Estimation of rumen microbial protein production from purine derivatives in urine'. IAEA-TECDOC-945 (International Atomic Energy Agency, Vienna, Austria).

11. Khochare A. B., Kank V. D., Gadegaonkar G. M., Salunke S. C. Strategic supplementation of limiting nutrients to medium yielding dairy animals at field level. In Proceedings of Vllth Animal Nutrition Association Conference. 2010. p. 30 (Bhubaneswar, India).

12. Kiersztejn M. I., Chervu M., Smogorzewski G. Z., Fadda J. M., Alexiewicz and Massry S.G., On the mechanisms of impaired phagocytosis in phosphate depletion. J.Am. Soc. Nephrol. 1992. no. 2, pp. 1484-1489.

13. Kohn R. A., Dinneen M. M., Russek-Cohen E. Using blood urea nitrogen to predict nitrogen excretion and efficiency of nitrogen utilisation in cattle, sheep, goats, horses, pigs and rats. J. Anim. Sci. 2005. issue 83. pp. 879-889.

14. Makkar, H.P. S. and Chen, X.B. (2004). Estimation of microbial protein supply in ruminants using urinary purine derivatives. (IAEA-CN-110, Vienna, Austria).

15. Nocek J. E., Socha M. T., Tomlinson D. J. The effect of trace mineral fortification level and source on performance of dairy cattle. J. Dairy Sci. 2006. issue 89. pp. 2679-2693.

16. NRC (2001). Nutrient Requirements of Dairy Cattle. 7th edn. (National Research Council, National Academy of Sciences: Washington, DC, USA).

17. Rahmatullah M., Boyde T. R. C. An improvement in determination of urea using diacetyl monoxine method with and without deproteinization. Clin. Chem. Acta. 1980. issue 107. pp. 3-9.

18. Shahjalal M. D., Bishwas M. A. A., Tareque A. M. M., Dohi H. Growth and carcass characteristics of goats given diets varying protein concentration and feeding level. Asian-Austral. J. Anim. Sci. 2000. issue 13, pp. 613-618.

19. Sherasia P. L., Phondba B. T., Hossain S. A., Patel B. P., Garg M.R. Impact of feeding balanced rations on milk production, methane emission, metabolites and feed conversion efficiency in lactating cows. Indian J. Anim. Res. 2016. issue 50 (4): $505-511$

20. Butler W. R., Calaman J. J., Beam S. W. Plasma and milk urea nitrogen in relation to pregnancy rate in lactation dairy cattle. J. Anim. Sci. 1996. issue 74. pp. 858-865.

21. Spears J. W. Micronutrients and immune function in cattle. Proceedings Nutr. Soc. 2000. issue 59, pp. 587-594.

22. Wittenberg, K. Enteric methane emissions and mitigation opportunities for Canadian cattle production systems. 2008. http://www.vido.org/beefinfonet/otherareas/pdf/Ccb Methane emmissionsWittenburg.pdf.

\section{References:}

1. Normy i raciony kormleniya sel'skohozyajstvennyh zhivotnyh [Standards and rations for feeding farm animals]: sprav. posobie. 3-e izdanie pererab. i dop. pod red. A. P. Kalashnikova, i dr. Moskva, 2003.

2. Baker, L.D., Ferguson, J.D. and Chalupa, W., 1995. Responses in urea and true protein of milk to different protein feeding schemes for dairy cattle. J. Dairy Sci., issue 78, pp. 2424-2434.

3. Bayat, A. and Shingfield, K. J., 2012. Overview of nutritional strategies to lower enteric methane emissions in ruminants. In 'Proceeding of Maataloustieteen Paivat, Helsinki, Finland, pp. 1-7.

4. Castillo, A. R., Kebreab, E., Beever, D. E., Barbi, J. H., Sutton, J. D., Kirby, H. C., France, J., 2001. The effect of protein supplementation on nitrogen utilisation in lactating dairy cows fed grass silage diets. J. Anim. Sci, issue 79, pp. 247-253.

5. Garg, M. R., Sherasia, P. L., Bhanderi, B. M., Phondba, B. T., Shelke, S. K. and Makkar, H. P. S., 2013. Effects of feeding nutritionally balanced rations on animal productivity, feed conversion efficiency, feed nitrogen use efficiency, rumen microbial protein supply, parasitic load, immunity and enteric methane emissions of milking animals under field conditions. Anim. Feed Sci. Technol. issue 179, pp. 24-35.

6. Haldar, S. and Rai, S.N., 2003. Effects of energy and mineral supplementation on nutrient digestibility and efficiency of milk production in lactating goats. Indian J. Anim. Nutr., issue 20, pp. 244-251.

7. Hawk, P. B., Oser, B. L. and Summerson, W. H., 1976. 'Physiological Chemistry.' 14th edn. (McGraw Hill Publishing Company Ltd.: London, UK).

8. Hennessy, D. W. and Nolan, J.V., 1988. Nitrogen kinetics in cattle fed a mature subtropical grass hay with and without protein meal supplementation. Aust. J. Agric. Res., issue 39, pp. 1135-1150.

9. Hutjens, M. and Chase, L.E., 2012. Interpreting milk urea nitrogen (MUN) values. Extension - America's researchbased learning network. http://www.extension.org

10. IAEA (1997). Estimation of rumen microbial protein production from purine derivatives in urine. IAEA-TECDOC-945 (International Atomic Energy Agency, Vienna, Austria).

11. Khochare, A.B., Kank, V.D., Gadegaonkar, G.M. and Salunke, S.C. (2010). Strategic supplementation of limiting nutrients to medium yielding dairy animals at field level. In 'Proceedings of Vllth Animal Nutrition Association Conference'. p. 30 (Bhubaneswar, India).

12. Kiersztejn, M.I., Chervu, M., Smogorzewski, G.Z., Fadda, J.M., Alexiewicz and Massry, S.G., 1992. On the Вісник Сумського національного аграрного університету 
mechanisms of impaired phagocytosis in phosphate depletion. J.Am. Soc. Nephrol., no. 2, pp. 1484-1489.

13. Kohn, R.A., Dinneen, M.M. and Russek-Cohen, E., 2005. Using blood urea nitrogen to predict nitrogen excretion and efficiency of nitrogen utilisation in cattle, sheep, goats, horses, pigs and rats. J. Anim. Sci., issue 83, pp. 879-889.

14. Makkar, H.P. S. and Chen, X.B. (2004). Estimation of microbial protein supply in ruminants using urinary purine derivatives. (IAEA-CN-110, Vienna, Austria).

15. Nocek, J.E., Socha, M.T. and Tomlinson, D.J., 2006. The effect of trace mineral fortification level and source on performance of dairy cattle. J. Dairy Sci., issue 89, pp. 2679-2693.

16. NRC (2001). Nutrient Requirements of Dairy Cattle. 7th edn. (National Research Council, National Academy of Sciences: Washington, DC, USA).

17. Rahmatullah, M. and Boyde, T.R.C., 1980. An improvement in determination of urea using diacetyl monoxine method with and without deproteinization. Clin. Chem. Acta, issue 107, pp. 3-9.

18. Shahjalal, M.D., Bishwas, M.A.A., Tareque, A.M.M., and Dohi, H., 2000. Growth and carcass characteristics of goats given diets varying protein concentration and feeding level. Asian-Austral. J. Anim. Sci., issue 13, pp. 613-618.

19. Sherasia P.L., Phondba B.T., Hossain S.A., Patel B.P. and Garg M.R., 2016. Impact of feeding balanced rations on milk production, methane emission, metabolites and feed conversion efficiency in lactating cows. Indian J. Anim. Res., issue 50 (4): 505-511

20. Butler, W.R., Calaman, J.J. and Beam, S.W., 1996. Plasma and milk urea nitrogen in relation to pregnancy rate in lactation dairy cattle. J. Anim. Sci., issue 74, pp. 858-865.

21. Spears, J.W., 2000. Micronutrients and immune function in cattle. Proceedings Nutr. Soc., issue 59, pp. 587-594.

22. Wittenberg, K., 2008. Enteric methane emissions and mitigation opportunities for Canadian cattle production systems. http://www.vido.org/beefinfonet/otherareas/pdf/Ccb Methane emmissionsWittenburg.pdf.

Borshchenko Valery Vladimirovich, Doctor of Agricultural Sciences, Associate Professor

Lavryniuk Oksana Oleksandrivna, Candidate of Agricultural Sciences, Associate Professor

Solonenko Natalia Igorivna, student

Solonenko Eugene Leonidovich, student

Krysan Serhiy Vasyliovych, student

Polissya National University

(Zhytomyr, Ukraine)

conversion in milk

Influence of balanced feeding rations on dairy productivity of crusts, substance exchange and efficiency of feed

Production studies to assess the impact of balanced diets on milk productivity of cows, metabolism and efficiency of feed conversion into milk were conducted on the population of Ukrainian black-spotted breed PSP "Novoselytsia" Popilnyansky district of Zhytomyr region, in the amount of 36 heads. The cows were in the second period of lactation, the average daily milk production was $13.9 \mathrm{~kg}$ with $4.1 \%$ fat. Research has optimized the lowest-cost diet using diet-balancing software. The diet was balanced in terms of metabolic energy, crude protein, calcium and phosphorus, in accordance with the feeding norms for cattle. All experimental animals were fed a balanced diet for 30 days, except for the 15-day adaptation period. Feeding cows with a balanced diet and improving the supply of calcium and phosphorus had a positive effect on increasing milk yield $4 \%$ fat by $0.7 \mathrm{~kg} / \mathrm{cow}(P<0.05)$. At the same time, the cost of feeding decreased by $17.0 \%$. Optimization of rations can improve metabolic processes in cows, similar studies show that the level of immunoglobulins and uric acid in the blood increases significantly, while the level of blood urea nitrogen (BUN) decreases $(P<0,01)$ from 18.2 to $15.0 \mathrm{mg} / \mathrm{dl}$. The conversion of feed into milk also improves from 0.8 to 1.0 . This study shows that balanced feeding of cows, after adjusting the rations in accordance with the norms of feeding, improves milk production, improves metabolic processes in the body and the efficiency of feed conversion into cow production conditions. Thus, a balanced diet of dairy cows improves nutrient utilization, milk production, microbial nitrogen supply, and feed conversion efficiency.

Key words: rations, milk productivity, cows, metabolism, efficiency, feed conversion.

Дата надходження до редакції: 09.06.2021 р. 